\title{
North American grooved-axe replication: A taphonomic experiment in central Connecticut
}

\author{
Matt Swieton \\ University of Otago. Dunedin, Otago, New Zealand. Email: swietonmaj@gmail.com
}

\begin{abstract}
:
Taphonomic experiments in lithic technology have been used to understand many facets of the archaeological record including site-formation processes, artifact displacement, and wear damage. The North American grooved-axe - an artifact type of which little technological attention has been given in the literature - is examined as a case study for a taphonomic experiment conducted in Central Connecticut. The use of an actualistic taphonomic experiment is used to generate an analogous experimental signature for archaeological grooved-axe manufacturing areas in North America. More specifically, the taphonomic experiment is used here to see if the isolated technological stage of impaction is archaeologically visible before short-term formation processes affect the manufacturing area in question. Impaction is a ground stone tool manufacturing technique that is otherwise known as pecking or hammer-dressing. Hypothesized archaeological traces of impaction include the recovery of flakes with macroscopic impaction wear and a lens of impaction slurry that is both visibly and texturally distinct. In addition to generating an experimental analogue for grooved-axe impaction, the replicative dimension of the taphonomic experiment is used to informally assess the plausibility of certain technological decisions in axe manufacture. Here, the use of quartzite impaction tools and expedient anvils in the production of North American grooved-axes are scrutinized.
\end{abstract}

Keywords: taphonomy; behavior; replication; grooved-axe; impaction

\section{Introduction}

Among the different types of proposed experimental typologies in archaeology (e.g., Mathieu 2002: 1-10; Reynolds 1999: 156-162) is the taphonomic experiment, which was advocated as a method for isolating and observing site-formation processes (Schiffer 1987), and also to understand the archaeological signature of behaviors (Gifford 1978; Tringham 1978). The taphonomic experiment is used here to both generate hypothetical archaeological 'traces' (sensu Binford 1980) of grooved-axe impaction areas and to make preliminary observations regarding short-term (approximately 6 months) site formation processes. Impaction is ground stone tool manufacturing technique that is otherwise known as pecking (Adams 2014a:33) or hammer-dressing (Dickson 1980).

Generally, the importance of taphonomic experiments has been emphasized in the study of lithic technology (Hiscock 1985). Many such experiments focused on identifying postISSN: 2055-0472. URL: http://journals.ed.ac.uk/lithicstudies/ 
depositional trampling wear (e.g., Eren et al. 2011; Balirán 2014:), artifact displacement (e.g., Cresson 2010; Homsey-Messer et al. 2016), isolating the effects of individual site-formation processes (e.g., Borazzo 2016), and even to examine the taphonomy of specific discarding behaviors (e.g., Borrero 2014). Taphonomic approaches to the formation of the archaeological record are increasingly utilized (e.g., Borazzo \& Weitzel 2014), but the taphonomy of North American grooved-axe impaction areas has not been thoroughly investigated (see Figure 1). Most experiments in ground stone technology have focused on use and usewear (e.g., Wright 1993; Liebowitz 2008; Adams 2014b; Dubreuil \& Savage 2014), but little experimental attention has been given to the technology and taphonomy of North American ground stone axe manufacturing areas (cf. Mills 1993; Mathieu \& Meyer 1997; Holladay 2010; Kinsella 2010). Grooved-axes have been recovered from many different regions in the Northeast (Wilbur 1979), Southwest (Heizer 1946), and regions in between (Barkley 1957; Miles 1963; Stephens 1969; King 1981; Hummell 1983; Butkus 1999). Although axes with impacted grooves in North America exhibit a broad range of technological variation through time and space, groove impaction is a common technological theme among most specimens; thus the varieties of North American grooved-axes are superficially presented here as a single category.

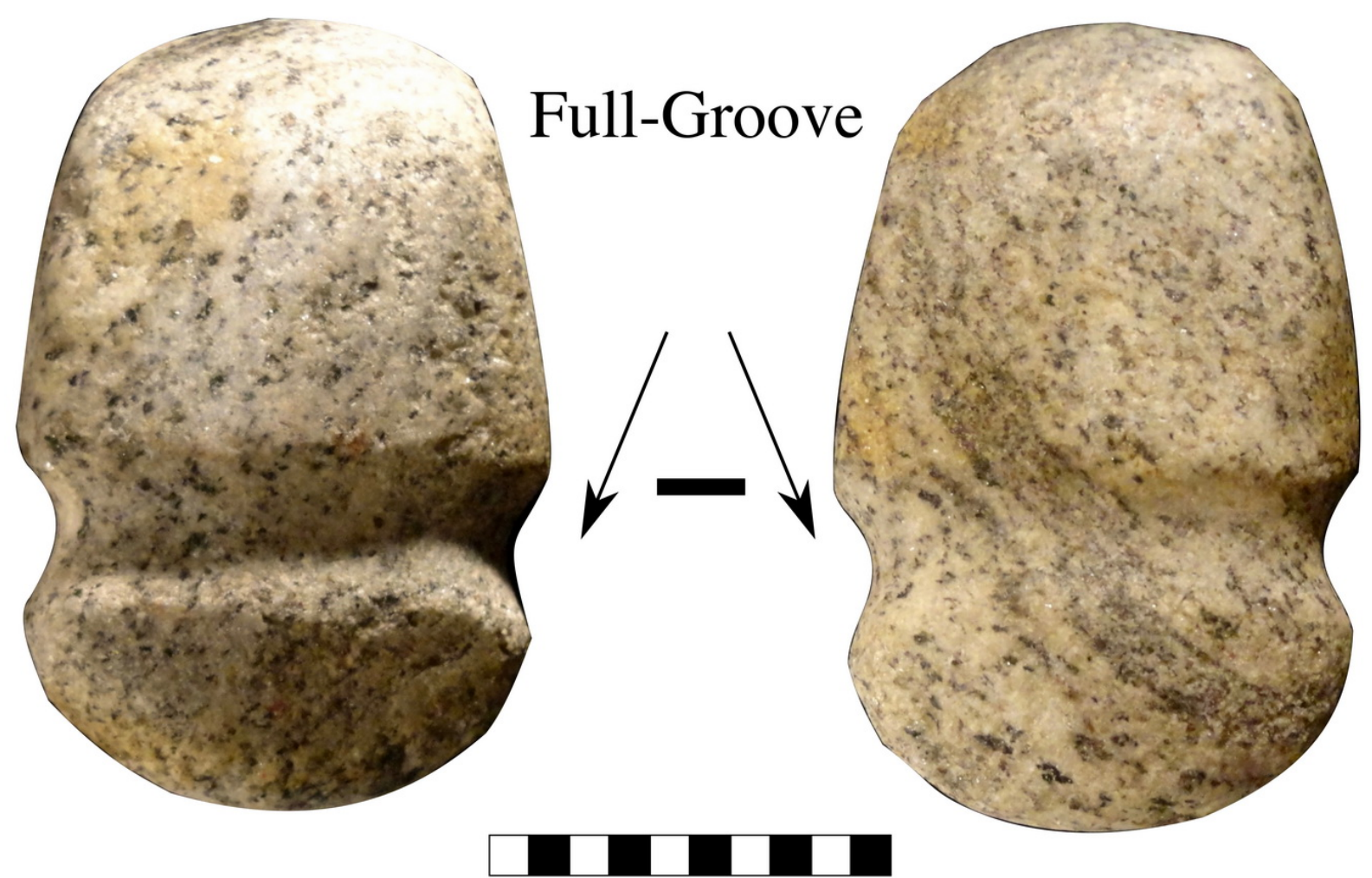

Figure 1. Obverse (L) and reverse (R) surfaces of the full-grooved axe replica. Scale bar = 10 centimeters.

\section{Methods}

The total impaction time was slightly under 40 hours, but working behavior was contained in the same location throughout the entire process. After axe impaction was completed, a 2x2 meter grid was imposed over the working site in a manner that ensured as much of the feature was encompassed as possible. The entire 2x2 meter grid was broken up into four $1 \times 1$ meter units, each of which was given its own designation and excavated in quadrants. Before excavation started, surface mapping of the work area began for all visible artifacts (see Figure 2). After the completion of this production stage the area was abandoned, 
but still under observation. Six months elapsed before the area was excavated. The impaction area was excavated by $50 \mathrm{~cm}^{2}$ quadrants and sifted through $1 / 8^{\text {th }}$ inch $(3.175 \mathrm{~mm})$ mesh; soil textures were recorded and soil colors were measured and recorded using a Munsell soil-color chart (Munsell Color 2009).

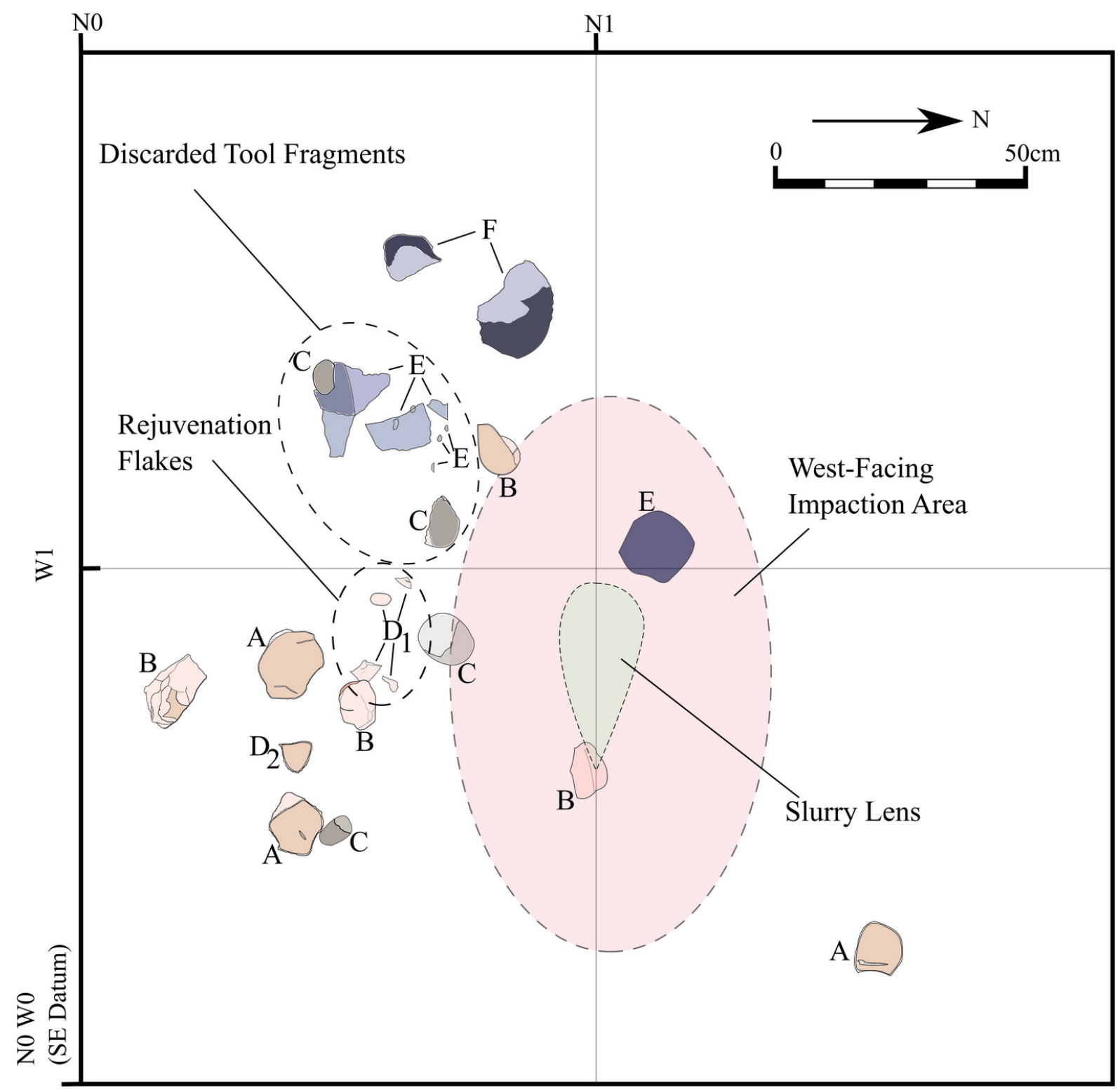

Figure 2. Surface map of the impaction area. The map depicts A) quartzite cobble impaction tools, B) flaked quartzite impaction tools, C) granite impaction tools, $\mathrm{D}_{1}$ ) quartzite rejuvenation flakes, $\mathrm{D}_{2}$ ) quartzite impaction flake, E) shale anvil and corresponding fragments, and F) teleolith.

\subsection{Raw Material Selection}

The required material was selected based on one subjective criterion: The minimization of energy expenditure in raw material procurement for the axe blank and impaction tools. Granite and quartzite were selected as the primary materials for the replication - both of which are ubiquitous in Central Connecticut - the latter being advantageous because it was easy to rejuvenate exhausted edges by removing rejuvenation flakes. Impaction was practiced on an immediately available piece of gneiss; thus producing a 'practice piece'. This is an artifact type that Shea (2015) called a 'teleolith', or a piece that was produced as the inadvertent byproduct of practicing. The gneiss teleolith (labelled ' $F$ ', Figure 2) was kept in the 2x2 meter 
grid, but was discarded just west of the main working area. An expedient shale anvil was brought into the unit (labelled E, Figure 2) - although the shale was not a durable anvil, it successfully prevented energy suppression from impaction on a grassy work surface. Many shale fragments were detached from the expedient anvil; however, fragments were detached from the reverse anvil surface as opposed to the obverse axe-supporting anvil surface. Throughout the $\approx 40$ hour cumulative impaction session the anvil was moved and used when appropriate.

\subsection{Reduction Strategy}

Grooved-axes are on display in two well-known museums in Connecticut: Yale Peabody Museum and the Mashantucket Pequot Museum. Without having direct access to archaeological material from either museum, the exemplars on display and figures featured in several archaeological publications served as an informal template for the replication. Although archaeological artifacts could not be properly examined for this study, important observations could be made from the exhibits; i.e., the grooves were still pitted from impaction while the bit faces were ground. Although the museum exemplars were not made of granite, early literature does mention its use in axe production (Wilbur 1979). Lucianne Lavin (personal communication) has indicated that the indigenous axe makers of Connecticut frequently used basalt.

Most of the impaction tools were cortical quartzite cobbles of varying sizes. In the early stages of the replication, two smaller granite impaction stones were sampled; both of which were destroyed but exhibited a battered surface that corresponded to the detachment of large fragments. The heavier cortical quartzite impaction tools - cobble tools - were used for decortification of the granite nodule and more intense reduction. The initial goals of reduction were two-fold: 1) To decortify the granite blank and 2) to work areas with irregularly protruding surfaces to create a symmetrical axe blank. After this was done, efforts were focused to create a more acute axe bit by carefully impacting the naturally rounded cobble.

While primary reduction and symmetry were done mostly with the quartzite cobble tools, flaked tools were introduced when a specific edge-morphology was required to achieve groove impaction (see Reid \& Pritchard-Parker 1993 for a similar utilization of unmodified and flaked quartzite impaction tools in metate manufacture and maintenance). Large tool blanks were struck from quartzite nodules and minimal flaking was used to achieve a tool morphology thought to best suit groove impaction. The largest of the flaked tools was used to start reducing the groove, and the smaller subsequent flaked tools were used for deepening the groove - a task that required slightly more precision. The flaked tools, during their use-life, gradually generated a crushed working edge along with impaction-induced use-flakes (sensu Hayes et al. 2014); thus changing the use-edge delineation of the tool over time. Maintaining the flaked quartzite impaction tools was figured to be the easiest response to an exhausted working edge; as such, a quartzite hammerstone was used to remove transverse rejuvenation flakes on the exhausted impaction tools. The removal of such flakes re-established an acute use-edge that was useful in deepening the hammer-dressed groove. Interestingly, these rejuvenation flakes exhibit unilateral plunging, on which evidence of intense macroscopic impaction wear was present (see Figure 3). The rejuvenation flakes are depicted as a cluster in Figure 2 located in the southwest unit of the $2 \times 2$ meter grid.

The axe preform was later taken out of the impaction area to a nearby sandstone slab where the axe was subjected to several strokes on a lubricated grindstone (sandstone netherstone). It was clear that the use of heavy cobble tools had created a severely pitted surface, which required more effort to grind out in the next stage. To make future grinding easier, an artificer could have used heavier tools for faster preform reduction and then used 
lighter impaction tools to alleviate the degree of surface pitting before grinding. Based on this experience, the author decided to invest more time on the impaction of the bit faces with the lighter flaked tools to reduce the degree of surface pitting and, ultimately, to make later grinding easier.

\section{Refitted Transverse \\ Rejuvenation Flake}

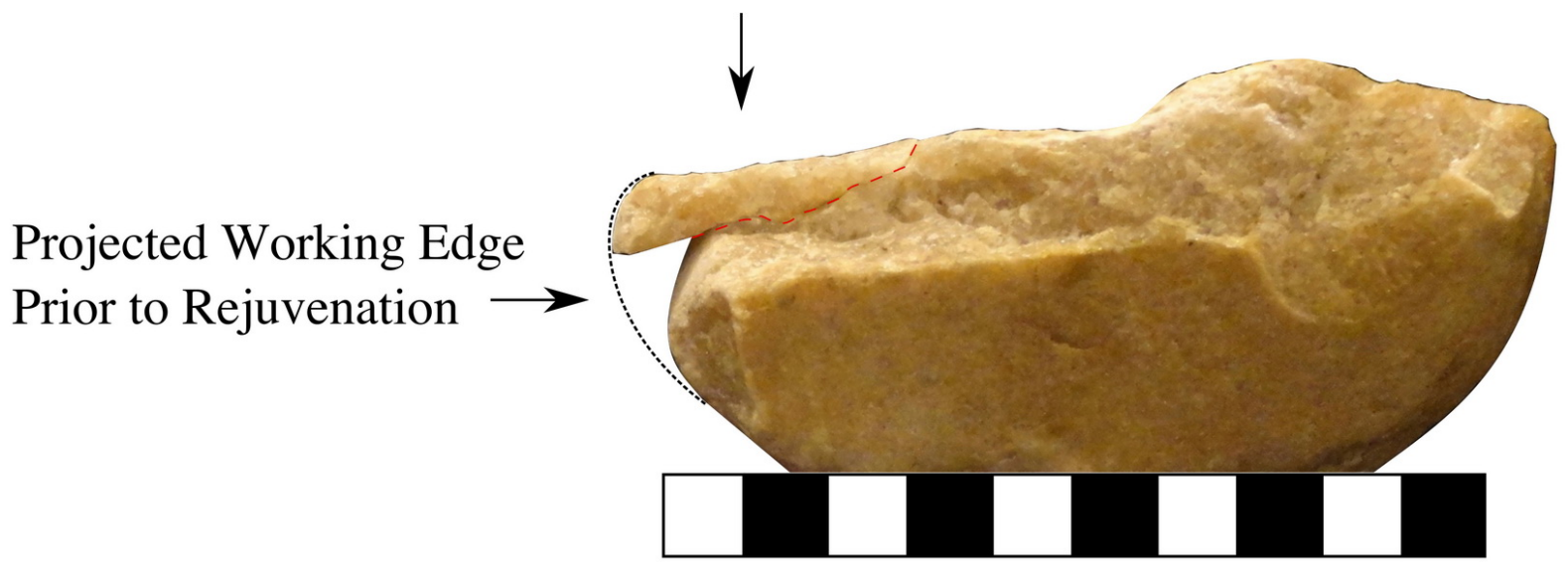

Figure 3. A flaked cobble tool depicted with the distal end of a refitted rejuvenation flake (red dotted-line). Upon refitting, the plunged lateral margin of the rejuvenation flake provides a projection of the use-edge prior to rejuvenation (black dotted-line). Scale bar $=10 \mathrm{~cm}$.

\section{Results}

The impaction area was left alone for six months before mapping and excavation began. One of the most interesting observations was a lens of impaction slurry corresponding to the area in which impaction occurred. Other technological replications in ground stone technology have also yielded rock powder - such replications include the production of green stone axes and adzes from Neolithic Italy (Lunardi 2008: 369) and the grinding of Neolithic Danish daggers (Callahan 2016: 87; Nunn 2006: 107). In the case of Neolithic Danish dagger replication, the reported slurry lenses consisted not only of flint, but also powder from the grindstone and additional grit (sometimes a crushed-flint sand or conventional beach sand). The slurry lens in this case consisted of impaction use-flakes, cortical granite, shale fragments, and quartzite and granite powders. Immediately after the work was done at the experimental axe impaction site, the location near the anvil - which withstood most of the impaction - was devoid of grass and a clear accumulation of slurry sat atop the ground surface. Many different formation processes were observed: Most notably, bioturbation by means of sparrows dust-bathing in the newly deposited lens. Additionally, the impaction site experienced heavy rains, and a single snowfall. The area was clearly demarcated with florescent flags and was also worked around with a lawn mower - another possible mode of site disturbance. The site itself was never mowed.

Soil color and texture were recorded for each of the 16 quadrants that comprise the 2x2 meter grid. A Munsell soil color chart was used to measure the soil for all quadrants, which yielded an overall reading of 10YR 3/4 (dark yellowish brown) with a texture that was described as a 'loamy silt'. There was one exception in the middle of the grid corresponding to the impaction-slurry lens; the sediment yielded a 10YR 6/1 (grey) reading with a texture described as a 'sandy silt' (Munsell Color 2009) (see Figure 4). Many of the impaction useflakes were found around or within the slurry lens, which demonstrates the plausibility of identifying an anthropogenic lens archaeologically. The slurry lens also contained the 
aforementioned cortical granite fragments from the start of the reduction; the detachment of these fragments only occurred when the cortical surface of the granite was subjected to heavy impaction via cobble tools (see Figure 5). No such fragments were produced after decortification.

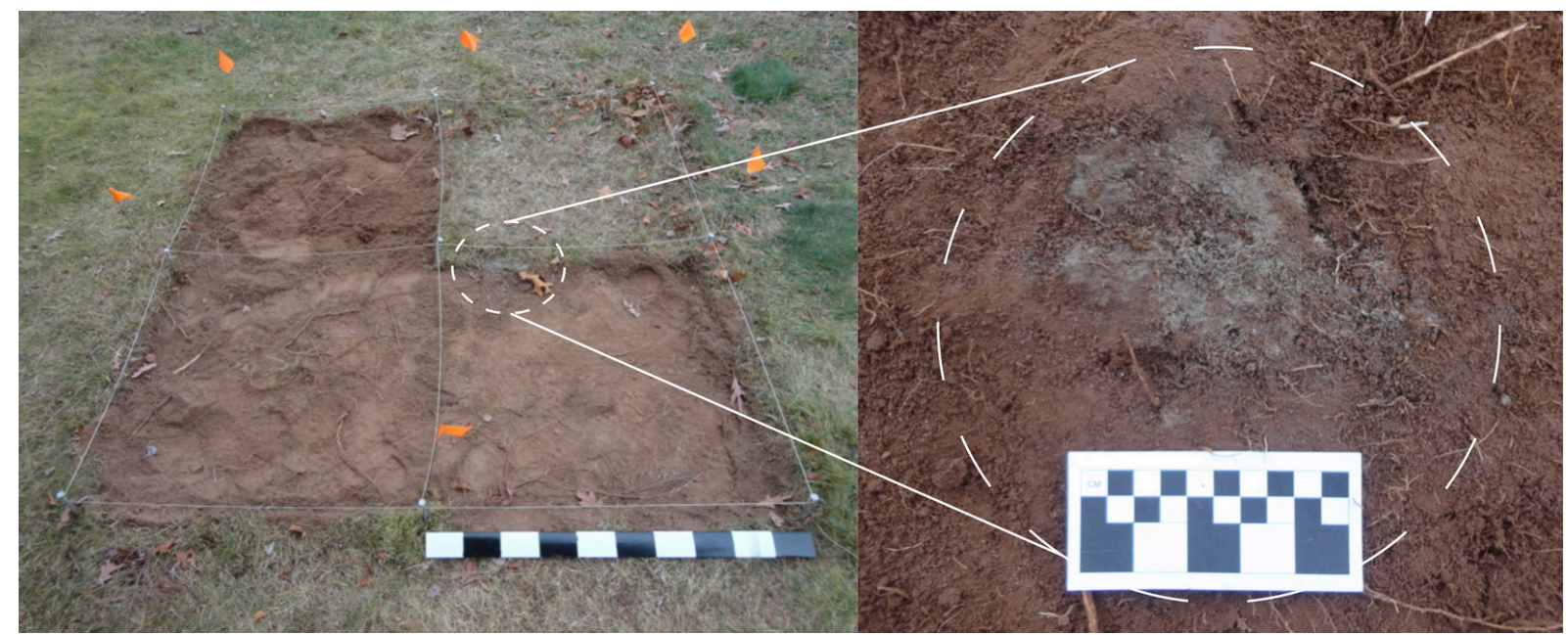

Figure 4. (L) The 2x2 meter grid partially excavated with an emphasis on the slurry lens (white dotted-line). (R) Close-up of the impaction-slurry lens below the sod layer. The dimensions of the lens in the sod layer were $37 \mathrm{~cm}$ (l) $\times 16 \mathrm{~cm}(\mathrm{w}) \times 1 \frac{1}{2} \mathrm{~cm}(\mathrm{t})$. Scale bar (left) $=1$ meter. Scale bar (right, top row) $=10$ centimeters.
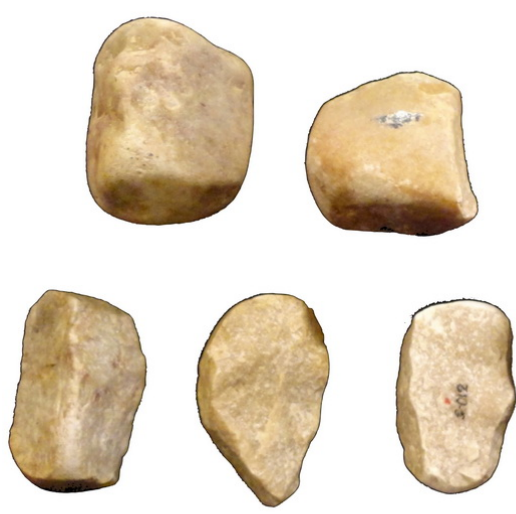

ana
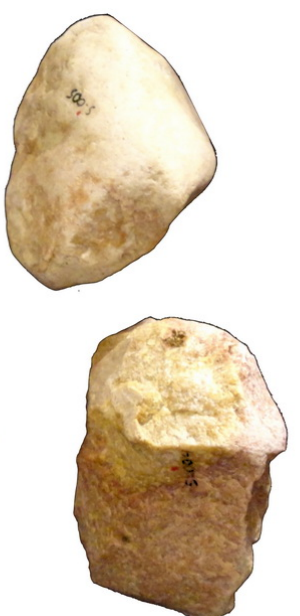

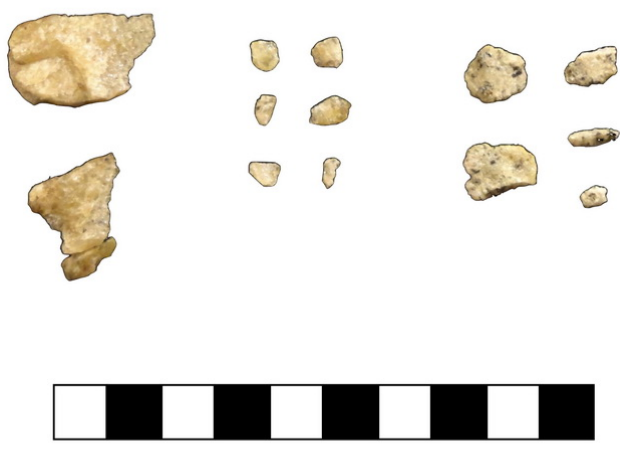

Figure 5. Various impaction tools (L) and different flake types (R). In the former: top row depicts quartzite cobble tools and the bottom row depicts flaked tools. In the latter: quartzite rejuvenation flakes (the bottom of which is refitted; featured in Figure 3), quartzite impaction use-flakes, and cortical granite fragments are depicted, respectively. Scale bar $=10$ centimeters.

Of the 16 quadrants that comprise the 2x2 meter grid, nearly half of the quadrants were sterile $(n=6)$. A total of 145 artifacts were recovered from the work area, and approximately $79 \%(n=114)$ of which were recovered from the four central quadrants of the $2 \times 2$ meter grid. Of the quartzite flakes that were recovered, a superficial distinction was made between an impaction flake and an impaction microflake. Microflakes, in this case, are any flakes recovered from a 1/8 inch $(3.175 \mathrm{~mm})$ screen that would not have been recovered in a 1/4 inch $(6.35 \mathrm{~mm})$ screen. The 'impaction' qualifier for these flakes refers to the behavioural cause of wear present on the use-flake platforms. Rejuvenation flakes - compared to impaction flakes - exhibit macroscopic impaction wear on the plunged lateral flake margins rather than on the platforms. 


\section{Discussion and Conclusion}

The results of this taphonomic experiment have yielded some practical observations that could have archaeological implications in identifying grooved-axe manufacturing areas despite the heavily speculative and arbitrary conditions of the replication. In addition to a slurry lens that is both colorfully- and texturally- distinct, use-flakes found in and around the lens contained evidence of impaction on either the platforms or on the plunged margins of larger flakes. I suspect that the slurry lens would have been produced regardless of the raw materials used in the impaction process; however, the archaeological preservation of such a lens is questionable. Quartzite and granite were not likely selected by prehistoric groups for axe manufacture since the production time in this replication was approximately 40 hours. Interestingly, if quartzite were selected to execute axe-grooving behaviour in antiquity, then perhaps maintenance tools (sensu Binford \& Binford 1966) -such as the hammerstone -would be necessary to rejuvenate working edges of the grooving impaction tools. More importantly, ideal hammerstones would probably be taken from the area after work was complete - as was the case in this replication - with the only archaeological visibility of such hammerstones being the resultant rejuvenation flakes. Overall, the taphonomic experiment - in this particular case - acts more as a controlled thought experiment used to visualize the predictions of an archaeological signature under specific technological parameters.

\section{Acknowledgements}

I would like to thank Lucianne Lavin for reviewing the manuscript and providing comments. Thanks to Jerzy Swieton for providing the land on which the experiment was conducted. Lindsey Clegg and Jesse Swieton both provided help in the excavation process; and Jesse Swieton provided exceptional help in surface mapping. Additionally, I would like to thank Mitch Irving and Ken Feder for proofreading an earlier version of this manuscript - and Lindsey Clegg for proofreading this version of the manuscript. Thanks to Jaime Macías for translating the abstract.

\section{References}

Adams, J.L. 2014a, Ground Stone Analysis: A Technological Approach (2nd ed.). The University of Utah Press, Salt Lake City, 336 p.

Adams, J.L. 2014b, Ground Stone Use-wear Analysis: A Review of Terminology and Experimental Methods. Journal of Archaeological Science, 48: 129-138. doi:10.1016/j.jas.2013.01.030

Balirán, C. 2014, Trampling, Taphonomy, and Experiments with Lithic Artifacts in the Southeastern Baguales Range (Santa Cruz, Argentina). In: Taphonomic Approaches to the Archaeological Record (Borazzo, K. \& Weitzel, C., Eds.), Facultad de Ciencias Sociales - UNICEN, Olavarría: p. 85-96.

Barkley, H. 1957, Comments of the Indian Axe. Central States Archaeological Journal, 4(2): 50-56.

Binford, L.R. 1980, Willow Smoke and Dogs' Tails: Hunter-Gatherer Settlement Systems and Archaeological Site Formation. American Antiquity, 45(1): 4-20. doi:10.2307/279653

Binford, L.R., \& Binford, S.R. 1966, A Preliminary Analysis of Functional Variability in The Mousterian of Levallois Facies. American Anthropologist, 68(2): 238-295.

doi:10.1525/aa.1966.68.2.02a001030 
Borazzo, K. 2016, Lithic Taphonomy in Desert Environments: Contributions from FuegoPatagonia (Southern South America). Quaternary International, 422: 19-28. doi:10.1016/j.quaint.2015.12.012

Borazzo, K., \& Weitzel, C. (Eds.) 2014, Taphonomic Approaches to the Archaeological Record, InterSecciones en Antropología. Facultad de Ciecias Sociales-UNICEN, Olavarria, $110 \mathrm{p}$.

Borrero, L.A. 2014, Multi-Surface Taphonomy. Shells, Garbage, and Floating Palimpsests. In: Taphonomic Approaches to the Archaeological Record (Borazzo, K. \& Weitzel, C., Eds.), Facultad de Ciencias Sociales- UNICEN, Olavarría: p. 13-20.

Butkus, E. 1999, Prehistoric Axes from Chicago. Central States Archaeological Journal, 46(3): 108-111.

Callahan, E. 2016, Neolithic Danish Daggers Vol. II: A Manual for Flintknappers and Lithic Analysts. Warwick House Publishing, Lynchburg, 288 p.

Cresson, J. 2010, Environmental Variables, Surface Displacement and Deposition of Lithic Artifacts: A Backyard Experiment. In: Experiments and Interpretation of Traditional Technologies: Essays in Honor of Errett Callahan (Nami, H.G., Ed.), Ediciones de Arqueologica Contemporanea, Buenos Aires: p. 365-380.

Dickson, F.P. 1980, Making Ground Stone Tools. Archaeology and Physical Anthropology of Oceania, 15(3): 162-167. doi:10.1002/j.1834-4453.1980.tb00335.x

Dubreuil, L. \& Savage, D. 2014, Ground stones: A Synthesis of the Use-Wear Approach. Journal of Archaeological Science, 48: 139-153. doi:10.1016/j.jas.2013.06.023

Eren, M.I., Boehm, A.R., Morgan, B.M., Anderson, R., \& Andrews, B. 2011, Flaked Stone Taphonomy: a Controlled Experimental Study of the Effects of Sediment Consolidation on Flake Edge Morphology. Journal of Taphonomy, 9(3): 201-217.

Gifford, D.P. 1978, Ethnoarchaeological Observations of Natural Processes Affecting Cultural Materials. In: Explorations in Ethnoarchaeology (Gould, R.A., Ed.), University of New Mexico Press, Albuquerque: p. 77-101.

Hayes, E., Fullagar, R., Clarkson, C., \& O'Connor, S. 2014, Usewear on the Platform: 'useflakes' and 'retouch-flakes' from Northern Australia and Timor. In: An Integration of the Use-Wear and Residue Analysis for the Identification of the Function of Archaeological Stone Tools: Proceedings of the International Workshop, Rome, March 5th-7th, 2012 (Lemorini, C., \& Cesaro, S.N., Eds.), BAR International Series Vol. 2649, Archaeopress, Oxford: p. 77-90.

Heizer, R.F. 1946, The Occurrence and Significance of Southwestern Grooved Axes in Southwestern California. American Antiquity, 11(3): 187-193. doi:10.2307/275561

Hiscock, P. 1985, The Need for a Taphonomic Perspective in Stone Artefact Analysis. Queensland Archaeological Research, 2: 82-97.

Holladay, D. 2010, A Case for Southwestern Grooved Axes: Why "Old-Style" Grooved Axes in the "Celt Age?" Bulletin of Primitive Technology, (39): 22-25.

Homsey-Messer, L., Ortmann, A., Roe, L., \& Cyr, H. 2016, Taphonomy and the Role of Experimentation in Microartifact Analysis. Southeastern Archaeology, 35(1): 65-69. doi:10.1179/2168472315Y.0000000015 
Hummell, G.R. 1983, The Half-Grooved Axes of Southeastern Iowa. Central States Archaeological Journal, 30(3): 122-123.

King, R. 1981, Variety in Grooved Axes Found in Northeasthern Oklahoma. Central States Archaeological Journal, 28(3): 130-133.

Kinsella, L. 2010, Responses to- A Case for Southwestern Grooved Axes: Why "Old-Style" Grooved Axes in the Celt-Age?" Bulletin of Primitive Technology, (39): 26-28.

Liebowitz, H.A. 2008, Wear Patterns on Ground Stone Implements from Tel Yin'am. In: New Approaches to Old Stone (Rowan, Y.M. \& J.R., E., Eds.), Equinox, London: p. 182195.

Lunardi, A. 2008, Experimental Testing with Polished Greenstone Axes and Adzes: Technology and Use. In: Prehistoric Technology 40 Years Later: Functional Studies and the Russian Legacy (Longo, L. \& Skakun, N., Eds.), British Archaeological Reports International Series Vol. 1783, Archaeopress, Oxford: p. 369-373.

Mathieu, J.R. 2002, Introduction -Experimental Archaeology: Replicating Past Objects, Behaviors, and Processes. In: Experimental Archaeology: Replicating Past Objects, Behaviors, and Processes (Mathieu, J.R., Ed.), BAR International Series Vol. 1035, Archaeopress, Oxford: p. 1-10.

Mathieu, J.R. \& Meyer, D.A. 1997, Comparing Axe Heads of Stone, Bronze, and Steel: Studies in Experimental Archaeology. Journal of Field Archaeology, 24(3): 333-351. doi:10.1179/009346997792208122

Miles, C. 1963, Indian and Eskimo Artifacts of North America. Bonanza Books, New York, $244 \mathrm{p}$.

Mills, P.R. 1993, An Axe to Grind: A Functional Analysis of Anasazi Stone Axes from Sand Canyon Pueblo Ruin (5MT765), Southwestern Colorado. Kiva, 58(3): 393-413. doi:10.1080/00231940.1993.11758214

Munsell Color 2009, Munsell soil-color charts. Munsell Color, X-Rite, Grand Rapids, Michigan, 19 p.

Myers, A. 1989, Reliable and Maintainable Technological Strategies in the Mesolithic of Mainland Britain. In: Time, Energy and Stone Tools (Torrence, R., Ed.), Cambridge University Press, Cambridge: p. 78-91.

Nunn, G. 2006, Using the Jutland Type IC Danish Dagger as a Model to Replicate Parallel, Edge-to-Edge Pressure Flaking. In: Skilled Production and Social Reproduction (Apel, J. \& Knutsson, K., Eds.), Societas Archaeologica Upsaliensis, Uppsala: p. 81-113.

Reid, D., \& Pritchard-Parker, M.A. 1993, Preliminary Results of a Replicative Study: Metate Re-Roughening, Pecking, or Pounding? Proceedings of the Society of California Archaeology, 6: 199-206.

Reynolds, P. 1999, The Nature of Experiment in Archaeology. In: Experiment and Design: Archaeological Studies in Honour of John Coles (Harding, A.F., Ed.), Oxbow, Oxford: p. 156-162.

Schiffer, M.B. 1987, Formation Processes of the Archaeological Record. University of Utah Press, Salt Lake City, 448 p. 
Shea, J.J. 2015, Making and Using Stone Tools: Advice for Learners and Teachers and Insights for Archaeologists. Lithic Technology, 40(3): 231-248. doi:10.1179/2051618515Y.00000000011

Stephens, B.W. 1969, The Half-grooved Axe. Central States Archaeological Journal, 16(3): 112-117.

Tringham, R. 1978, Experimentation, Ethnoarchaeology, and the Leapfrogs in Archaeological Methodology. In: Explorations in Ethnoarchaeology (Gould, R.A., Ed.), University of New Mexico Press, Albuquerque: p. 169-199.

Wilbur, C.K. 1979, The New England Indians. The Globe Pequot Press, Chester, 108 p.

Wright, M.K. 1993, Simulated Use of Experimental Maize Grinding Tools from Southwestern Colorado. Kiva, 58(3): 345-355. doi:10.1080/00231940.1993.11758214 


\title{
Replicación del hacha acanalada norteamericana: Un experimento tafonómico en el centro de Connecticut
}

\author{
Matt Swieton \\ University of Otago. Dunedin, Otago, Nueva Zelanda. Email: swietonmaj@gmail.com
}

\section{Resumen:}

Los experimentos tafonómicos en tecnología lítica han sido utilizados para entender muchas facetas de los registros arqueológicos incluyendo procesos de formación de sitios, desplazamiento de artefactos, y daño por desgaste. El hacha acanalada norteamericana -un artefacto al que se le ha prestado poca atención tecnológica en la literatura- es examinado como caso de estudio para un experimento tafonómico realizado en el centro de Connecticut. El uso de un experimento tafonómico realista es utilizado para generar una firma experimental análoga para las áreas de fabricación de hachas acanaladas arqueológicas en América del Norte. Más específicamente, el experimento tafonómico es utilizado aquí para ver si la etapa tecnológica aislada de impactación es arqueológicamente visible antes de que los procesos de formación de corto plazo afecten al área de fabricación en cuestión. La impactación es una técnica de fabricación de herramientas de piedra de la tierra que también es conocida como picoteo o martillo-vestidor. Las trazas arqueológicas de impactación hipotetizadas incluyen la recuperación de escamas con desgaste por impacto macroscópico y una lente de lodo de impactación que es tanto visible como texturalmente distinta. Además de generar un análogo experimental para la impactación del hacha acanalada, la dimensión replicativa del experimento tafonómico es usada para evaluar informalmente la verosimilitud de ciertas decisiones tecnológicas en la fabricación del hacha. Aquí, los usos tanto de herramientas de impactación de cuarcita como de yunques expeditivos en la producción de hachas acanaladas norteamericanas son escudriñados.

Palabras clave: tafonomía, comportamiento, replicación, hacha acanalada, impactación 